\title{
Records of Jerdon's baza Aviceda jerdoni (Blyth, 1842) from eastern Nepal
}

\section{Sanjaya Raj Tamang ${ }^{1,2 *}$ (iD $\mid$ Amrit Kumar Poudel ${ }^{1,3}$ (D) $\mid$ Pratik Pandeya ${ }^{4}$ (D)}

\author{
${ }^{1}$ ForestAction Nepal, Kathmandu, Nepal \\ ${ }^{2}$ Kathmandu Forestry College, Nepal \\ ${ }^{3}$ Faculty of Mathematics and Natural Sciences, University of Greifswald, Germany \\ ${ }^{4}$ Agriculture and Forestry University, Nepal \\ *Correspondence: sanjaytamang841@gmail.com
}

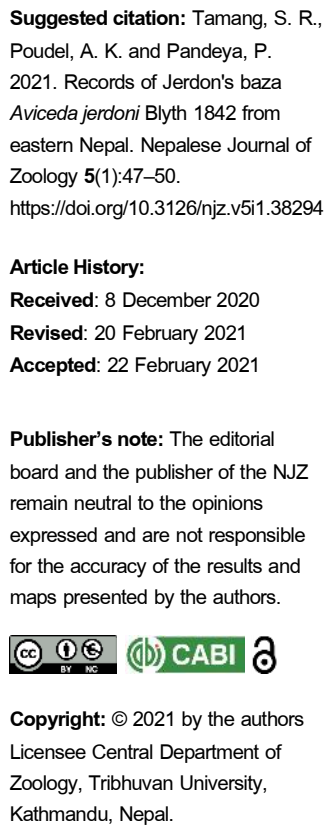

\section{(c) $(1)($ (b) $\mathrm{CABI}$ ○}

Copyright: $\odot 2021$ by the authors Licensee Central Department of Zoology, Tribhuvan University, Kathmandu, Nepal. International 2016). It has been recorded globally from Bangladesh, Bhutan, Brunei, Cambodia, China, India, Indonesia, Laos, Malaysia, Myanmar, Nepal, Philippines, Singapore, Sri Lanka, Thailand and Vietnam between 200-1100 m asl (BirdLife International 2016). Among five subspecies (Clark et al. 2020), Aviceda jerdoni jerdoni is recorded in Nepal. The raptor was first recorded in Nepal from Dharan Forests Important Bird Area (Basnet et al. 1999; Basnet et al. 2000). Further few sporadic observations were made by different observers from the same area in 2000, 2001, 2008 and 2011 and also from Chitwan National Park in 2000, 2003, 2006, 2008 and 2012 (Inskipp et al. 2016). The species has also been recorded from Morang district in 2004 (Basnet et al. 2006). In Satasidham Forest, Jhapa, a pair of Jerdon's baza was sighted in April and October 2017 and a single individual was sighted in June 2017 from the same area (Anish Timsina Pers. Comm., February 5, 2021). Limited distribution and scarce sightings of the species provides limited data about the species from Nepal.

The species is listed under the Critically Endangered category in Nepal's Red List of Birds (Inskipp et al. 2016). It has been listed as a resident species of Nepal by BirdLife International (2016). Grimmett et al. (2016) have mentioned about its breeding in Nepal and Inskipp et al. (2016) have also reported it to be probably a resident breeder in Nepal. Jerdon's baza was observed displaying and carrying food in May 2000 in Dharan forests (Benstead \& Benstead 2000). Similarly, a copulating pair of this species was also observed in March 2011 in the same region (Inskipp et al. 2016). This paper presents the records of the species from hill forests, foothills and plains from eastern Nepal with nesting information from eastern hills.

\section{2 | Materials and methods}

\section{1 | Study area}

This study was conducted in forest of Mai Municipality $\left(26^{\circ} 45^{\prime} \mathrm{N}\right.$, $\left.87^{\circ} 52^{\prime} \mathrm{E}\right)$ and Suryodaya Municipality $\left(26^{\circ} 53^{\prime} \mathrm{N}, 88^{\circ} 4^{\prime} \mathrm{E}\right)$ of Ilam District and Jalthal Forest of Haldibari Rural Municipality $\left(26^{\circ} 50^{\prime} \mathrm{N}, 88^{\circ} 01^{\prime} \mathrm{E}\right)$ of Jhapa District. Forest of Mai Municipality which lies in Siwalik region was mainly composed of Schima wallichii, Castanopsis indica and Shorea robusta. The forest in Suryodaya Municipality lying in mid-hills region was majorly composed of Schima-Castanopsis forest whereas Jalthal Forest 
located in Terai region was dominated by Shorea robusta. The location map of the study area has been shown in the Fig. 1.

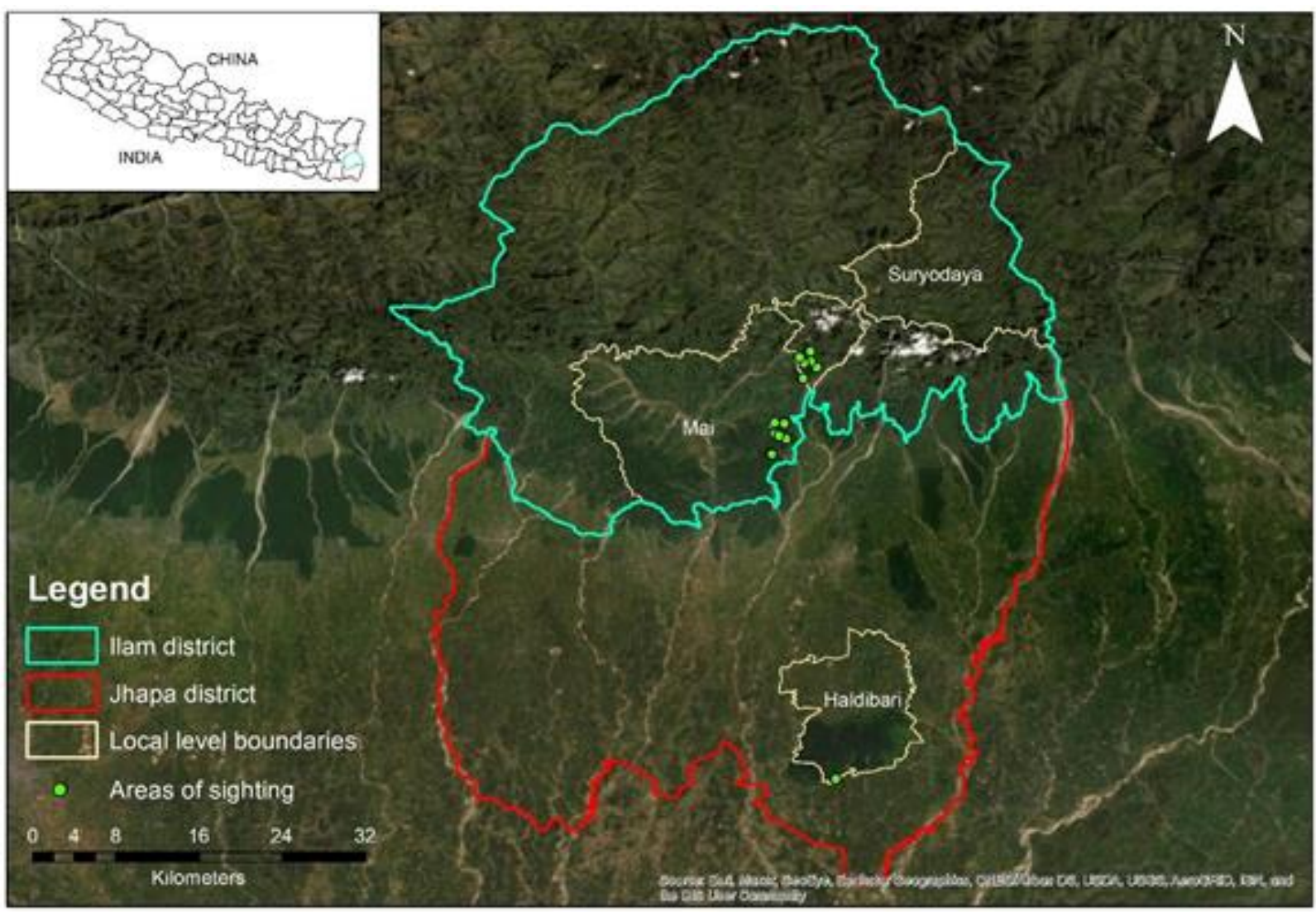

Figure 1. Map showing the areas of sighting of Jerdon's baza

\section{2 | Data collection and analysis}

Data were recorded from opportunistic surveys and observations during bird diversity study from the areas of llam and Jhapa districts. Surveys were conducted during 2018/19 in the hill forests of Mai Municipality and Suryodaya Municipality, Ilam District and Jalthal Forest of Haldibari Rural Municipality, Jhapa District, Nepal. Two observers walked through the existing trails for the survey. The site of observation of the species was recorded using a handheld GPS receiver.

For the proper identification of the species, Grimmet et al. (2016) was followed. Individual was identified with its distinctive long and erect white-tipped black crest, broad wings (pinched in at base) and fairly long tail (Grimmet et al. 2016). Photographs of the species were taken whenever possible and confirmation of the species with experts was done with the help of such photographs. Furthermore, informal discussions with local people were made regarding their observation and understanding of the species. Farmers near the location of nest were interviewed with open-ended questions related to their knowledge of the species. In addition to it, secondary literatures were reviewed thoroughly regarding this species to analyze its record in different parts of Nepal.

\section{3 | Results}

\section{1 | Species data}

Altogether 18 sightings of Jerdon's baza were made from the two districts during the entire survey period (Table 1). In llam District, the species was sighted 14 times from community forests (CFs) nearby each other in Mai Municipality (Dalthahar CF, 6; and Sukhani CF, 2) and Suryodaya municipality (Gitange CF and adjacent areas, 6). Individuals were sighted singly in different locations of llam district and at least one individual was recorded in each visit during the study in different months (January, April, June, and October 2018). In the Jalthal forest of Haldibari rural municipality, Jhapa District, four individuals (Durgavitta CF, 4) were seen perching in neighboring trees during a survey in September 2019. The elevation range of the records lies between $70 \mathrm{~m}-1048 \mathrm{~m}$ with $70 \mathrm{~m}$ at Durgavitta CF, Haldibari, Jhapa, and $1048 \mathrm{~m}$ at a forest patch in Suryodaya, Ilam. Fig. 1 shows the locations of Jerdon's baza sighted during the study and Fig. 2 shows a Jerdon's baza perching on a tree branch, observed in llam district. 
Table 1. Details of record of Jerdon's baza recorded in the study area

\begin{tabular}{|c|c|c|c|c|c|c|c|c|}
\hline SN & Recorded site & $\begin{array}{l}\text { \# individuals } \\
\text { sighted }\end{array}$ & Date of sighting & $\begin{array}{l}\text { Time of } \\
\text { sighting }\end{array}$ & $\begin{array}{l}\text { Behavior of } \\
\text { bird }\end{array}$ & Latitude $\left({ }^{\circ} \mathrm{N}\right)$ & Longitude $\left({ }^{\circ} \mathrm{E}\right)$ & $\begin{array}{l}\text { Elevation } \\
\text { (m asl) }\end{array}$ \\
\hline 1 & \multirow{6}{*}{ Suryodaya } & 1 & $02 / 04 / 2018$ & $08: 57$ & Perching & 26.80971 & 87.97152 & 463 \\
\hline 2 & & 1 & 04/04/2018 & 09:35 & Perching & 26.81461 & 87.96690 & 620 \\
\hline 3 & & 1 & 03/06/2018 & 08:18 & Nesting & * & * & 980 \\
\hline 4 & & 1 & 04/06/2018 & 09:10 & Perching & 26.81857 & 87.95655 & 1048 \\
\hline 5 & & 1 & $12 / 10 / 2018$ & $08: 37$ & Flying & 26.79979 & 87.95996 & 526 \\
\hline 6 & & 1 & $13 / 10 / 2018$ & $10: 14$ & Perching & 26.82368 & 87.96627 & 776 \\
\hline 7 & \multirow{8}{*}{ Mai } & 1 & 09/01/2018 & $11: 40$ & Flying & 26.74770 & 87.94500 & 215 \\
\hline 8 & & 1 & $11 / 01 / 2018$ & 09:20 & Flying & 26.75245 & 87.93522 & 269 \\
\hline 9 & & 1 & $06 / 04 / 2018$ & $08: 16$ & Perching & 26.75938 & 87.93307 & 325 \\
\hline 10 & & 1 & $06 / 04 / 2018$ & $08: 42$ & Perching & 26.76154 & 87.93516 & 309 \\
\hline 11 & & 1 & 09/06/2018 & 09:38 & Perching & 26.75033 & 87.93919 & 230 \\
\hline 12 & & 1 & $10 / 06 / 2018$ & $08: 25$ & Flying & 26.73478 & 87.93103 & 225 \\
\hline 13 & & 1 & $14 / 06 / 2018$ & 09:00 & Perching & 26.73431 & 87.93295 & 224 \\
\hline 14 & & 1 & $11 / 10 / 2018$ & $08: 22$ & Flying & 26.76086 & 87.94340 & 275 \\
\hline 15 & Haldibari & 4 & 09/09/2019 & $08: 40$ & Perching & 26.45273 & 87.98796 & 70 \\
\hline
\end{tabular}

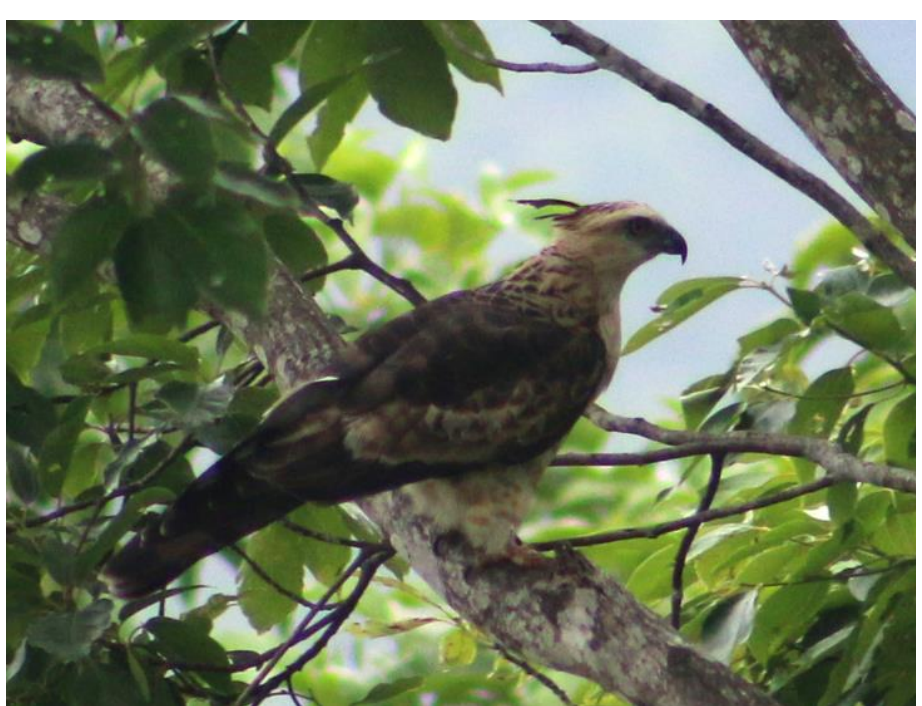

Figure 2. Jerdon's baza observed during the survey in llam (Photo credit: S. R. Tamang)

\section{2 | Nesting information}

A single nest of the species (Fig. 3) was recorded from the forest of Suryodaya, llam district during the study in 2018. The area consisted of sub-tropical broadleaved forest. Schima wallichii and Castanopsis indica were the major tree species found in the area. A female lying flat on the nest was observed from the ground. The nest was built up of dry twigs and leaves in one of the top branches of a Schima wallichii. The total height and diameter at breast height ( $\mathrm{dbh}$ ) of the tree were $20 \mathrm{~m}$ and $54 \mathrm{~cm}$ respectively. The nest was however located at a height of $16 \mathrm{~m}$ from the ground. The elevation of the base of the nesting tree was $980 \mathrm{~m}$ asl. The nesting tree was located at the edge of the forest with agricultural land on the other side and approximately 300 $\mathrm{m}$ from the nearest human settlement.

\section{3 | Threats}

Owing to its nature of being unperturbed to minor disturbances (also observed while photographing it as it perched on low branches and did not make quick responses or fly away while moving near on several accounts), this species seems vulnerable to hunting. Further, unintentional poisoning of the species by feeding on poisoned rats could pose threat to species as rat poisoning is common around. Therefore, along with habitat degradation and fragmentation, hunting and other activities like poisoning in potential prey could be threats to the conservation of the species. Such activities could pose

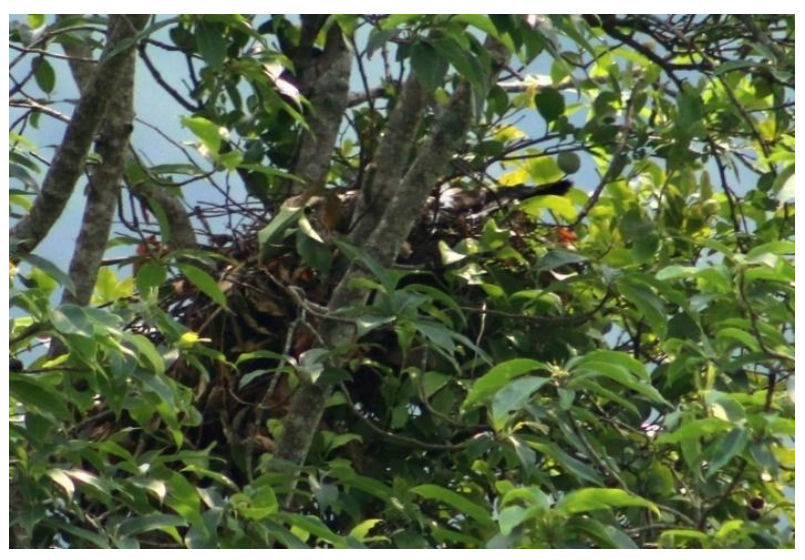

Figure 3. Nest of Jerdon's baza (Photo credit: S. R. Tamang) 
even more threats in case of habitat like in Nepal where their distribution has been very limited, directing a small resident population of the species.

\section{4 | Discussion}

This paper presents several records of the species from forests of Ilam and Jhapa districts as new reported sites for Jerdon's baza in Eastern Nepal. It was recorded in a wide altitudinal range of 70 to $1048 \mathrm{~m}$ asl which presents a new altitudinal record of its distribution both globally and nationally. Inskipp et al. (2016) have reported the elevation range of the species in Nepal to be limited to $150-250 \mathrm{~m}$. The record of the species at $1048 \mathrm{~m}$ during the study also extends its national upper elevational range from 250 $\mathrm{m}$ to $1048 \mathrm{~m}$ asl. Similarly, with previous distribution known to be in the altitude range of 200-1100 m globally (BirdLife International 2016) globally, sighting at $70 \mathrm{~m}$ in Jalthal presents a record of Jerdon's baza at lowest altitude with an extension of global elevation range to $70 \mathrm{~m}$ in lowlands. The unique Jalthal Forest is a mixed lowland forest with its microclimate often owing to hill species which might have made it suitable for use by Jerdon's baza. But a group of individuals observed during the survey and no further observations during subsequent winter and summer surveys provides a little clue about the residential evidence of the species from the forest.

The nesting information and observation of the species in four different months of a year supplements and strengthens the information on breeding of Jerdon's baza in Nepal. Though probable breeding has been reported before by Inskipp et al. (2016), this is the first confirmed breeding record of the species from Nepal. The presence of nests at the forest edge in relatively open canopy interestingly aligns with observations of various previous studies (Buij 2000; Shivkumar \& Prakash 2005; Nair 2007) where nests were recorded from similar habitats. This may be accounted to ease of access to food and provides some clues on the behavioral ecology of the species. However, nesting in open canopy areas may increase the risk of nest depredation by humans and other wildlife.

\section{5 | Conclusions}

As this paper only presents findings from opportunistic surveys further research on the species is necessary to get more details on its population, ecology and distribution. Proper awareness programs regarding the importance of bird species and its conservation seem very important in the area.

\section{Acknowledgements}

We are thankful to Darwin Initiative, project ref no: 26-022 led by Forest Action Nepal which funded our bird diversity study in Jalthal, Jhapa. Our special thanks go to Carol Inskipp, Dr. Hem Sagar Baral and Dr. Lilanath Sharma for their guidance and motivation in preparation for this note. We would also like to thank the locals of Suryodaya-15, Ilam and Haldibari-4, Jhapa for helping during field assessment.

\section{Authors' contributions}

Tamang, S. R. carried out the field data collection; Tamang, S. R., Poudel, A. P. and Pandeya, P. wrote the manuscript. All the authors contributed to the finalization of the draft and gave approval for the publication.

\section{Conflicts of interest}

Authors declare no conflict of interest.

\section{ORCID}

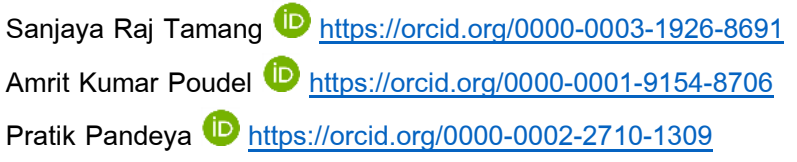

\section{References}

Basnet, S., Halt, P. and Karki, R. 1999. Jerdon's baza Aviceda jerdoni: a new species for Nepal. Danphe 8(2-4):1-2.

Basnet, S., Holt, P. and Karki, R. 2000. Jerdon's baza Aviceda jerdoni: a new species for Nepal. Forktail 16:170.

Basnet, Y. R., Tamang, B. and Gautam, B. 2006. Bird diversity and habitat status at Raja Rani Community Forest, Bhogteny, Morang, Nepal. Danphe 15(2/3):4-7

Benstead, P. and Benstead, C. 2000. Trip report: Nepal, 25 April-27 May, 2000.

http://www.camacdonald.com/birding/tripreports/Nepal00.html. Accessed on 15 June 2020.

BirdLife International. 2016. Aviceda jerdoni. The IUCN Red List of Threatened Species 2016: e.T22694956A93480971. https://dx.doi.org/10.2305/IUCN.UK.20163.RLTS.T22694956A9 3480971.en. Downloaded on 14 June 2020

Buij, R. 2003. Breeding behaviour of Jerdon's baza Aviceda jerdoni at Gunung Leuser National Park, Sumatra, Indonesia: the first nesting record for Sumatra. Forktail 19:139-141.

Clark, W. S. and G. M. Kirwan. 2020. Jerdon's Baza (Aviceda jerdoni), version 1.0. In Birds of the World (J. del Hoyo, A. Elliott, J. Sargatal, D. A. Christie, and E. de Juana, Eds.). Cornell Lab of Ornithology, Ithaca, NY, USA. https://doi.org/10.2173/bow.jerbaz1.01

Grimmett, R., Inskipp, C., Inskipp, T. and Baral, H. S. 2016. Birds of Nepal: Revised Edition. Bloomsbury Publishing.

Inskipp, C., Baral, H. S., Phuyal, S., Bhatt, T. R., Khatiwada, M., Inskipp, T., Khatiwada, A., Gurung, S., Singh, P. B., Murray, L., Poudyal, L. and Admin, R. 2016. The status of Nepal's Birds: the National Red List Series. Zoological Society of London. www.himalayannature.org. Accessed on 14 June 2020.

Nair, M. V. 2007. On the occurrence of Jerdon's baza Aviceda jerdoni in Simlipal Tiger Reserve, with some observations on behavior and vocalization. Indian Birds 3(2):61-62.

Sivakumar, S. and Prakash, V. 2005. Nesting of Jerdon's baza Aviceda jerdoni and Black baza A. leuphotes in Buxa Tiger Reserve, West Bengal, India. Forktail 21:169-171. 